\title{
Искра Христова-Шомова
}

Софийски университет „Св. Климент Охридски”

\section{Небесният симпозиум. Коментарите към Йов 1:6 във византийската и славянската традиция ${ }^{1}$}

Катената на книга Йов вероятно е била съставена през втората половина на V в. Съставителите са разполагали с изключително богата библиотека от библейски книги, екзегетични и богословски съчинения, сред които са били и Хексаплите на Ориген (вж. Hagedorn \& Hagedorn, 1994; Христова-Шомова, 2007). Тъй като трудът на Ориген е обхващал около 15 тома и от VI в. нататък следите му се губят, а е бил ползван в Кесария Палестинска през IV в. от Евсевий Кесарийски и в началото на V в. от св. Йероним, можем да предположим, че катената е съставена именно там.

Йов 1:6 е мястото, където се говори за събирането на Божиите синове. Библейският текст гласи: „А един ден, като дойдоха Божиите синове да се представят пред Господа, между тях дойде и Сатаната”. В това кратко изречение са въведени две понятия, едното почти непознато за предход-

1 Вариант на този текст е поместен в: Христова-Шомова, 2016, с. 291-304.

This work was supported by the Bulgarian Ministry of Education and Science.

Competing interests: no competing interests have been declared.

Publisher: Institute of Slavic Studies, PAS.

This is an Open Access article distributed under the terms of the Creative Commons Attribution 3.0 PL License (creativecommons.org/licenses/by/3.0/pl/), which permits redistribution, commercial and non-commercial, provided that the article is properly cited. () The Author(s) 2016. 
ната традиция на Свещеното писание, а другото - съвсем ново. Това са Божиите синове (на еврейски: „синовете на Елохим”) и Сатаната. Затова към този стих в катената са включени обширни коментари. За съставителите е било много важно обяснението на думите „Божиите синове”.

Не може с точност да се определи автентичното значение на еврейския текст. Той кореспондира с Бит. 6:2, където се казва: „Божиите синове, като гледаха, че човешките дъщери бяха красиви, вземаха си за жени от всички, които избираха”. И на двете места се говори за божии

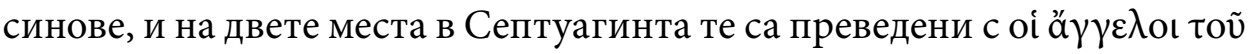
$\theta \varepsilon o \tilde{v}$, но в Codex Alexandrinus в Бит 6:2 първоначално е стояло vió тои̃ $\theta \varepsilon о \tilde{v}$, което е било изтрито и заменено с ä $\gamma \gamma \varepsilon \lambda о$. Вероятно тук е отразена стара митологична представа за божии синове (при това синове на много богове, тъй като Елохим е в множествено число), като в Бит 6:2 става дума за йерогамия: брачен съюз на божии синове с човешки дъщери. Тази древна митологична представа е запазена в ханаанския фолклор и е отразена в Книга на Енох, но талмудическата традиция дава и друг коментар на Бит. 6:2 - според някои от еврейските тълкуватели под Божии синове трябва да се разбират представителите на благородни племена, надарени с изключителни физически и духовни качества, които постепенно са били претопени.

Тенденцията е в Септуагинта и двете места да се превеждат с „ангели Божии" (макар да не е сигурно, че първоначалните преводи са били такива, както показва Codex Alexandrinus), но всяко от тях има различна традиция на коментарите. Според ранните църковни отци в Битие става дума за паднали ангели, но св. Августин обръща внимание на това, че ангелите не могат да се женят, и смята, че на това място става дума за потомците на Ноевия син Сит. Споменаването на Божии синове в книга Йов е в съвсем друг контекст. Християнската концепция вижда в това място Небесен симпозиум, праобраз на събирането на ангели в небесата, което ще се извърши при раждането на Божия син, по време на Христовите подвизи, а след това - и при подвизите на светците. Паралелът е съвсем основателен, защото ангелите, които ще ликуват при честването на християнските светци, по подобен начин са се събрали, за да отдадат почит на праведника Йов. И в този случай, както и в по-късните почитания на светците, ситуацията е една и съща - небесните войнства се сбират, защото делата на земна личност са се оказали толкова значими, че да бъдат прославени на небесата. В своя гръцко-християнски облик 
това място кореспондира с друго място от книга Йов: 38:7, където Бог прославя сам себе си като демиург и казва, че при сътворението на звездите е бил възпят от всички ангели.

Към Йов 1:6 в катената са подбрани разнообразни коментари, включително извадки от съчинения, които не са посветени на тълкуване на Йов 2 . Коментирани са както Божиите синове, така и противникът (Сатаната), но много повече внимание е отделено на ангелите.

На първо място са поместени по два откъса от трактатите За небесната йерархия и За църковната йерархия от Ареопагитиките, в които се обяснява природата на ангелите като свръхкосмически разум. Изтъкват се тяхната неудържима любов към невещественото, т. е. към божествената красота, и техният неотклонен стремеж към вечното единение с висшата и непримесена светлина, в резултат на които те неизменно спазват своя ред и са напълно непоколебими и неизменни в своята богоподобна природа, неподвластни на промяна към зло. Защото свещеният разум на свръхкосмическите духове е проникнат от несекваща божествена любов и е чужд на всякакво зло и забвение. Те са съвършено чисти и непорочни, защото дори и някой от тях да се е подвел от злото, той е отпаднал от небесното съобщество и е бил увлечен в мрака на падението на отстъпните пълчища. Но за небесната йерархия трябва да се посочи, че низшите чинове в нея се пречистват от божественото озарение, което достига до тях и ги въздига към съвършено богопознание и богосъзерцание.

Следва съвсем кратък откъс от 28-о слово на св. Григорий Богослов, в което се казва, че ангелите възпяват Божието величие. След това е поместен малък текст от Слово за св. Дух на св. Василий Велики, в което също се говори за природата на ангелите. По-нататък е включена част от коментар на Теодор Мопсуетски към Книга на пророк Захария, в който се казва, че всяко действие на ангелите и на дявола се извършва по Божие изволение и според Божия промисъл. Следват още два пасажа от За небесната йерархия, отново по един кратък пасаж от Григорий Богослов и Василий Велики, още два откъса от Ареопагитиките, а след тях - част от коментара на Григорий Нисийски към Песен на песните (Осмо слово), в който се говори за Божията същност като вечно добро. След това е поместен коментарът към това място от Олимпиодор, в който

2 Данните са въз основа на т. нар. Г-редакция, публикувана в критично издание с богат апарат от съпрузите Хагедорн (Hagedorn \& Hagedorn, 1994, с. 190-199). 
обаче също не се говори за съдбата на Йов, а за местата, където обитават ангелите и дяволът. Следва кратък коментар от Йоан Златоуст, който в повечето източници е даден като анонимен, но е идентифициран от съпрузите Хагедорн. Както обикновено, той е най-конкретен и коментира случая на Йов, като посочва, че дяволът е Божи инструмент да бъде изпитан праведникът. Следва кратък коментар от Олиомпиодор, който също по-често се дава като анонимен. В него е обяснена ролята на ангелите и на дявола в човешкия живот - ангелите го закрилят, а дяволът му пречи. Тук се съдържа важното уточнение, че и ангелите, и дяволът присъстват в човешкия живот, затова са позиционирани заедно в библейския разказ, а не защото дяволът действително би могъл да се яви заедно с ангелите в небесата.

Подобно по замисъл е следващото обширно тълкувание от Полихроний Апамейски, в което се разяснява ролята на ангелите и на дявола в Божия промисъл. Докато ангелите се стремят да привлекат човека към себе си и да създадат хармония, дяволът воюва с него и му се противо-

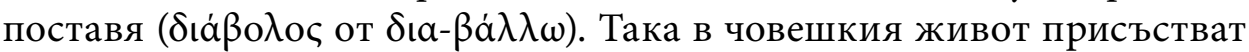
двете начала - на съгласието и на раздора. Коментарите към този стих завършват с кратък текст от Евагрий Понтийски, в който се пояснява, че ангелите са вездесъщи и знаят всичко, което става в света.

Така катената съдържа хор от различни гледни точки, в които от различни страни се коментират ангелите и дявола и тяхното присъствие в божествената уредба на света и в човешкия живот. От цялата полифония можем да разберем, че ангелите имат несъставна природа без примес или стремеж към зло и неизменно присъствие край Бога, че те съставляват свръхкосмически разум, като изпитват непроменливо влечение или любов ( $\varepsilon \omega \varsigma)$ към божественото и възпяват величието на Бога. Тяхната роля в човешкия живот е да бъдат доброто начало, което притегля хората към единство и хармония, докато ролята на дявола е да тегли човека към противопоставяне. Докато ангелите могат да обитават и земята, и небесните селения, мястото на дявола е само на земята. Действията и на ангелите, и на дявола са част от всеобхватния Божи промисъл, а сам Бог е абсолютно добро. Така в отговор на небесния симпозиум сме свидетели на земен симпозиум на свети отци, реализиран в катената. В това многозвучие обаче може да се долови общият замисъл на съставителя на катената. Източниците не са подбрани произволно, а са подчинени на обща идея и тя е значението на небесния симпозиум, природата на 
безплътните сили и тяхната неразделна връзка с божественото съвършенство. От направения преглед ясно се вижда, че дяволът е поставен на заден план и в много от коментарите изобщо не става дума за него, а ако се споменава, то е само за да се определи мястото му спрямо ангелския събор. Може да се каже, че катената към книга Йов не е просто сбор от извлечения от други книги, а истински авторски труд, който дава своя насока във възприемането на книгата и свой отпечатък върху източната християнска култура. Не случайно във византийската практика книга Йов се преписва преди всичко в състава на катената, а и това е едно от произведенията с най-богата и интересна традиция на илюстриране.

Нека разгледаме славянските преводи на това място в катената. Катената на книга Йов има два независими славянски превода, като и двата са направени от т. нар. Г-редакция, но от различни гръцки ръкописи ${ }^{3}$ Единият е представен в три преписа. Два от тях са рилски от XV в.: ръкопис PM4/14, Рилският сборник на Владислав Граматик от 1456 г. (Книга Йов е разположена на л. 158a-1916, коментарите са в съкратен вид) и ръкопис PM1/4 от последната четвърт на XV в., писан с ресавски правопис (вж. Христова-Шомова, 2007, с. 13). Третият е препис, правен от Висарион Хилендарец в Зографския манастир през 1503 г., който се пази в Библиотеката на Румънската академия на науките в Букурещ под № 96 (вж. Яцимирский, 1905, с. 644-645; Ангелов, 1978, с. 266; Христова-Шомова, 2007, с. 19). Другият превод засега е известен по единствен препис на инок Гавриил от 1412 г., който се пази в ГИМ, Син 202 (вж. Горский \& Невоструев, 1857, с. 53-59). Дж. Трифунович предполага, че това може би е автограф на преводача (Трифуновић, 1983). Вероятно и двата превода са правени от сръбски книжовници, но ще ги наричам условно „рилски” и „хилендарски”4. В хилендарския превод са включени голяма част от изброените дотук коментари, макар и не всички. Както и в гръцките източници, тълкуванията започват с пасажите от Ареопагитиките, следват текстовете на Василий Велики и Григорий Богослов, в променен ред, двата кратки коментара от Йоан Златоуст и Олимпиодор, но без имената на авторите им, откъсите от Теодор Мопсуетски, Олимпиодор и Полихроний Апамейски. В рилския превод има само два кратки коментара: Златоустовият и Олимпиодоровият, като авторите не са посочени, а двата са дадени с общото указание тлък.

3 За двата превода вж. по-подробно Христова-Шомова, 2006.

4 За някои сръбски думи в рилския превод вж. Reinhart (2012). 
Въз основа на тези две славянски версии на катената на книга Йов може да се направи сравнение на преводи, осъществени приблизително по едно и също време на Балканите. Нека първо да сравним преводите на пасажите от Ареопагитиките в цялостния превод на корпуса у Исая Серски (по най-ранния препис от Гилф. 46 от XIV в., за който се предполага, че е автограф на преводача) и в хилендарския превод на катената (в ръкописа на инок Гавриил, Син. 202 от 1412 г.).

\section{Из За небесната йерархия II, 4}

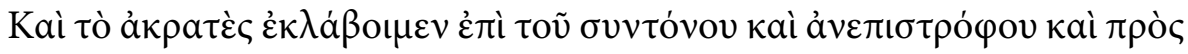

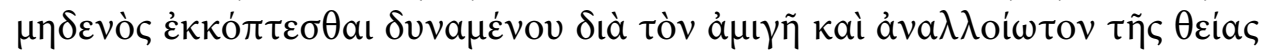

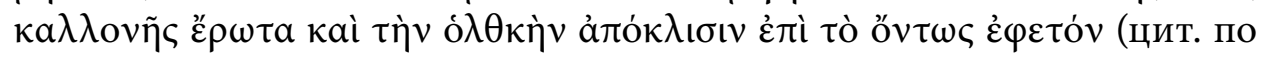
изданието Hagedorn \& Hagedorn, 1994, с. 191).

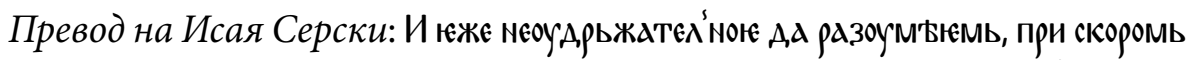

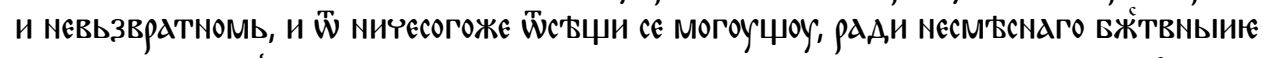

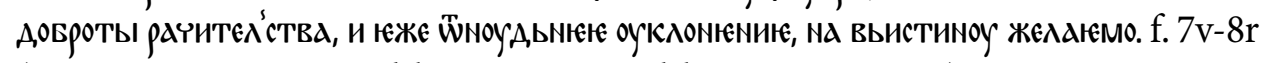
(цит. по изданието Fahl, Harney, \& Fahl, 2011, cc. 38-39).

Хилендарски превод на Катената на книга Йов: Иєжє меодръжимоє прїєх“"

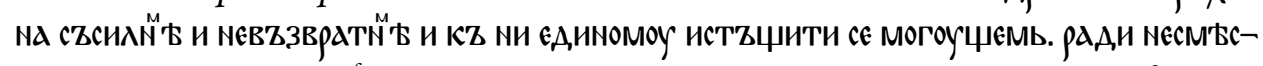

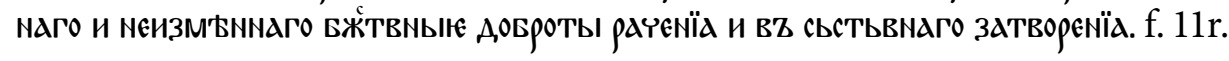

\section{Из За небесната йерархия VII, 2}

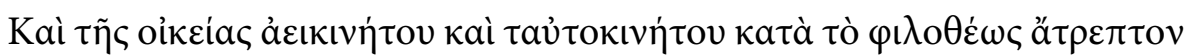

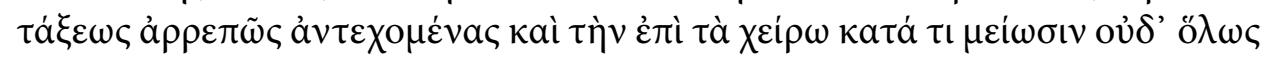

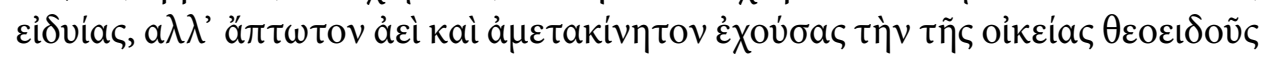

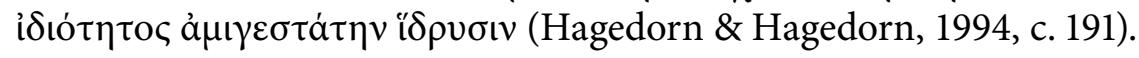

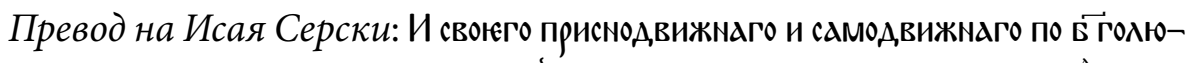

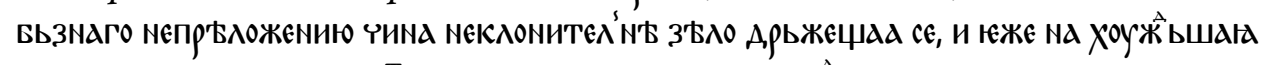

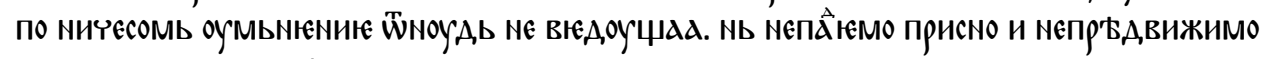

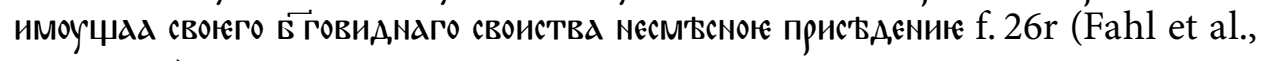
2011, c. 75).

Хилендарски превод на Катената на книга Йов: И своєГо приснодвижндаго

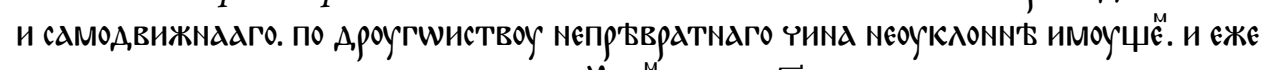

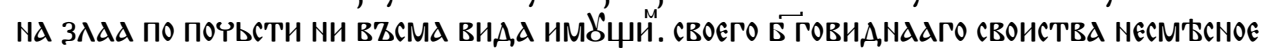
оутврZжӒєнїє. f. 11r. 


\section{Из За църковната йерархия IV, 5}

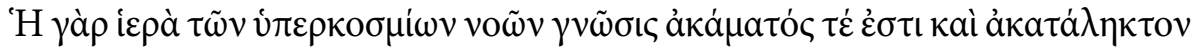

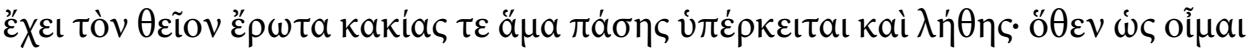

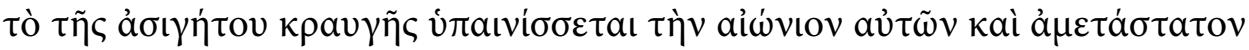

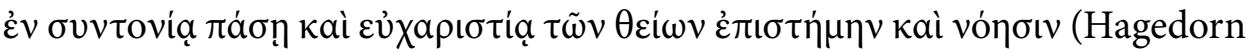
\& Hagedorn, 1994, c. 191).

Превод на Исая Серски: Сџ єенмын во пр'њмнрныи оумшвьь разоумь. нетроу-

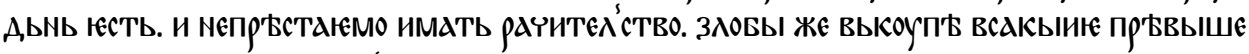

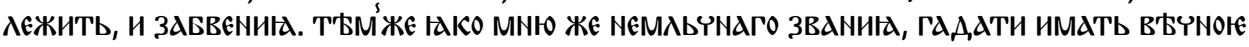

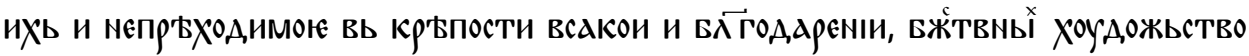
и разоум'ънике. f. 255r. (Fahl et al., 2011, с. 533).

Хилендарски превод на Катената на книга Йов: Иво с ченнын пр'вмир-

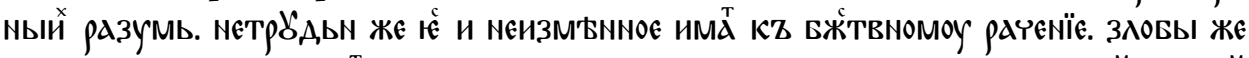

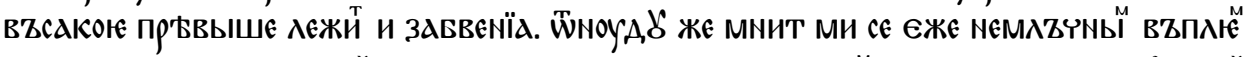

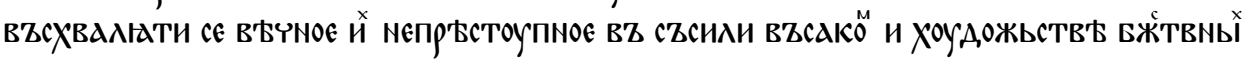

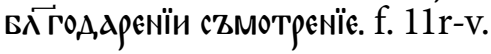

\section{Из За църковната йерархия VI, 6}

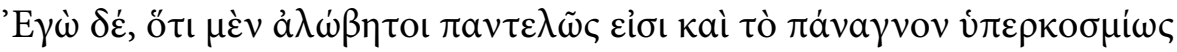

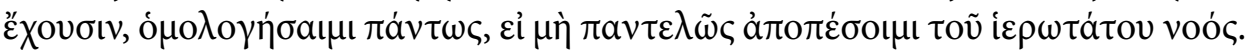

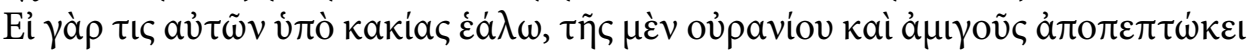

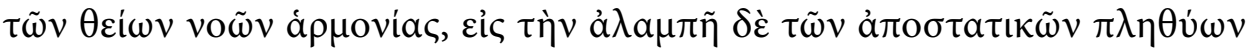
$\dot{\varepsilon} \varphi \dot{\varepsilon} \rho \varepsilon \tau o \pi \tau \tilde{\omega} \sigma \iota v$ (Hagedorn \& Hagedorn, 1994, c. 191).

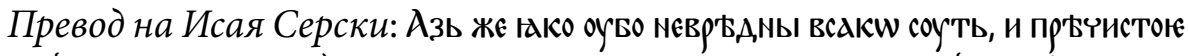

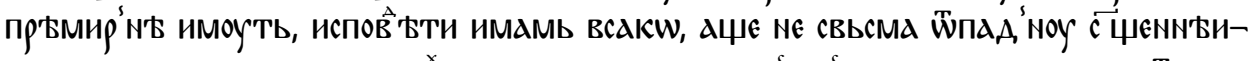

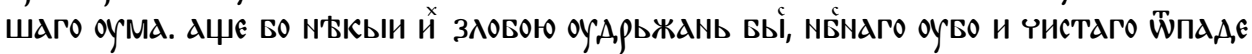

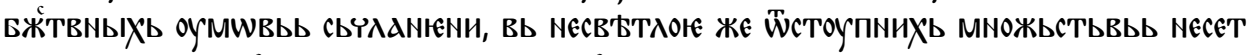

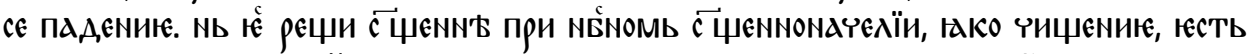

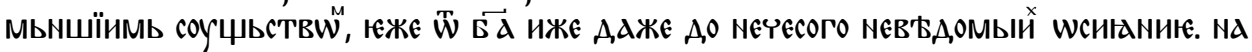

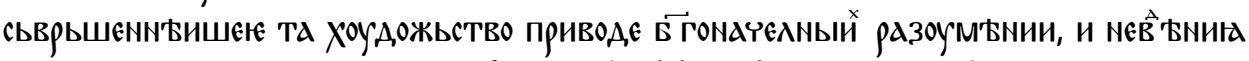
ихже неоу Хоудожьство им'БХоу. f. 275v. (Fahl et al., 2011, с. 574).

Хилендарски превод на Катената на книга Йов: Аз же ґко لББш

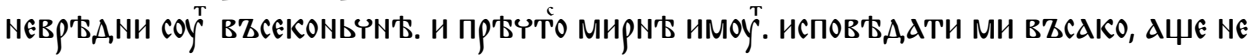

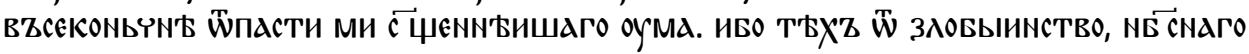

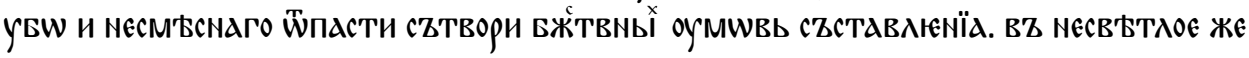




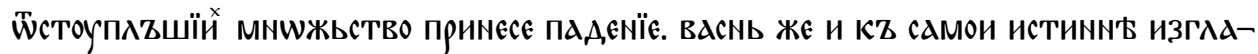

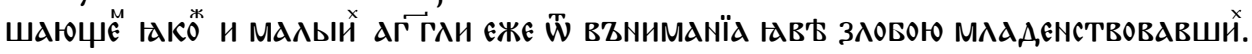

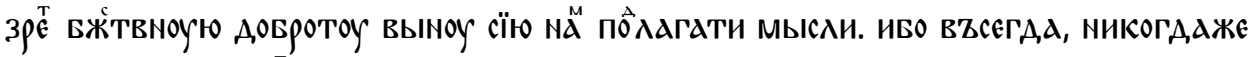

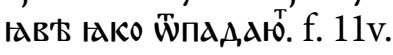

Прави впечатление предпочитанието към образувания с наставката -тєль в превода на Исая Серски: нєоудрьжительною срещу нєоудрьжимо

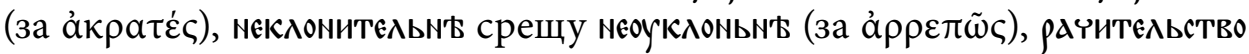

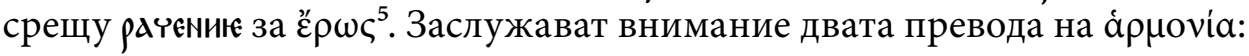
сZстАвлєниюе У ГавриИл И сZчАєнєниюе У Исая.

В хилендарския превод намираме по-свободни преводачески реше-

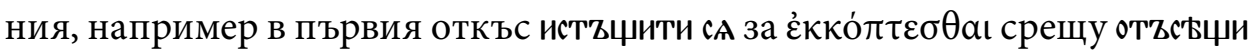
са у Исая, което съответства точно на структурата на гръцкия глагол:

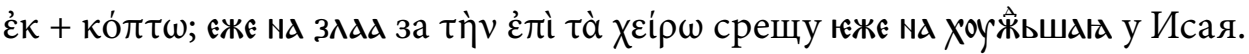
Думата $\chi \varepsilon i \rho \omega \nu$ означава 'по-слаб, по-неиздръжлив, по-некачествен', и оттам 'по-лош', така че тук преводът със зъло е доста свободен и замъглява значението на текста, в който се казва, че ангелите са неподатливи на отслабване, че не могат да имат по-некачествена и несъвършена при-

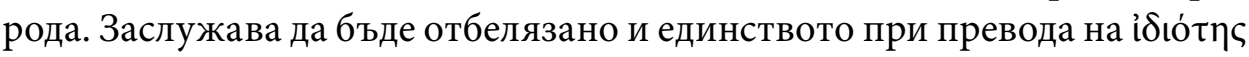
със своиство, което отговаря точно на значението на гръцката дума, която означава 'индивидуалност, своеобразие, собствена характеристика'.

По-нататък нека сравним преводите на тълкуванията на Йоан Златоуст и Олимпиодор в хилендарския и в рилския превод на Катената на книга Йов по преписите на инок Гавриил (Син. 202) и на Висарион Хилендарец (Румънска АН 96).

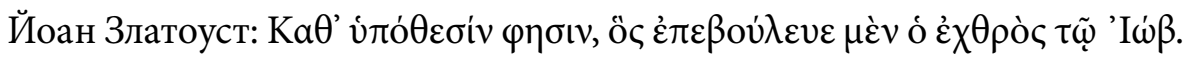

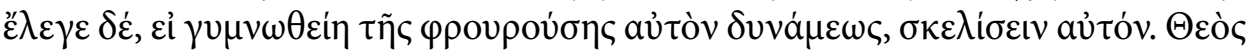

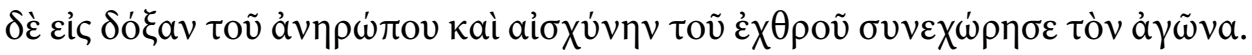

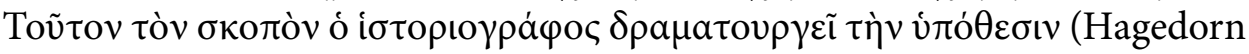
\& Hagedorn, 1994, c. 196-197).

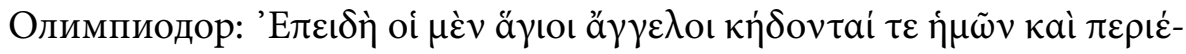

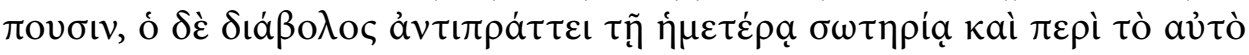

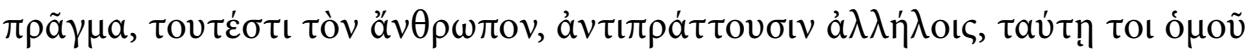

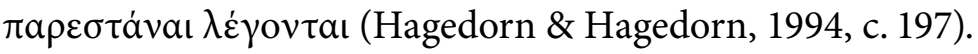

\footnotetext{
5 За употребата на прилагателните с наставка -тельнъ в този превод вж. Keipert (1985).
} 


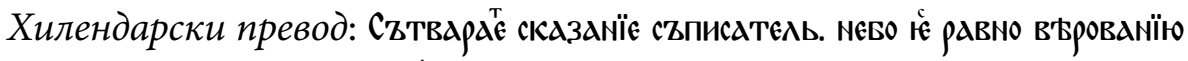

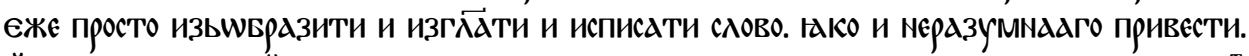

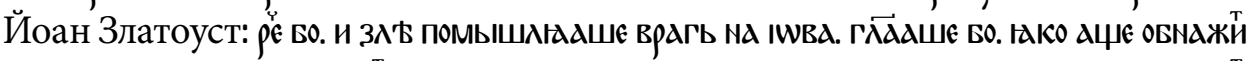

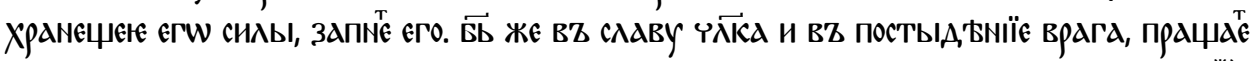

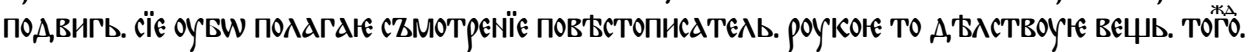

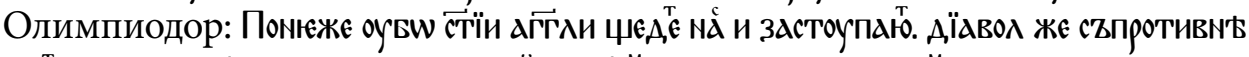

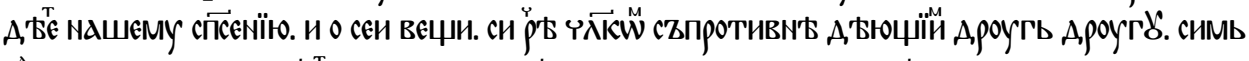

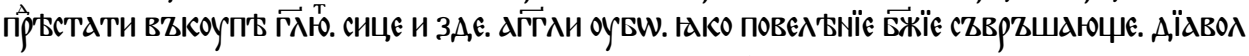

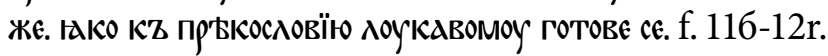

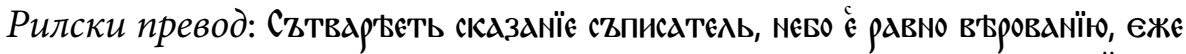

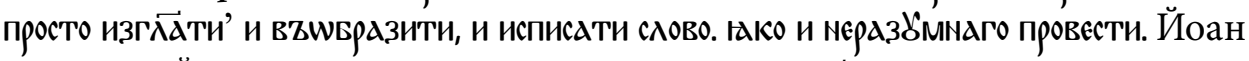

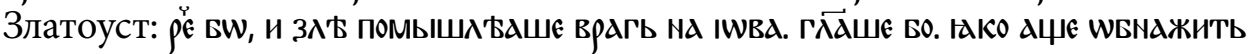

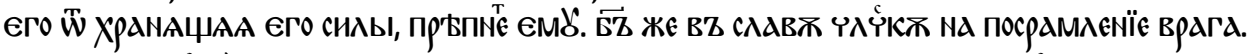

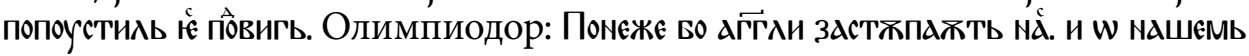

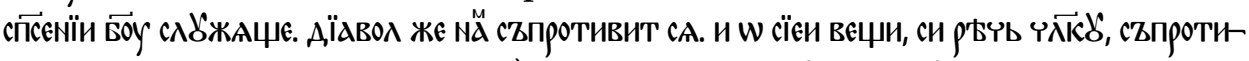

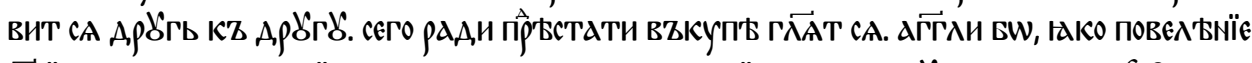

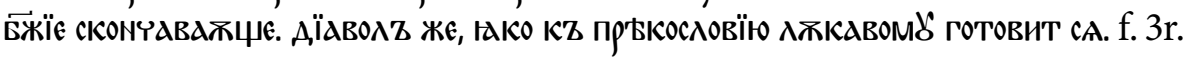

И в двата превода коментарите са въведени с встъпително изречение, което липсва в изданието на Хагедорн, но очевидно е присъствало в двата различни източника на двата превода на катената. Последната фраза от коментара на Олимпиодор, която се открива и в двата превода, също липсва в изданието на Хагедорн. При тези два коментара има значителна близост в двата превода, но това не може да наведе на предположение за заимстване на единия от другия, понеже като цяло двата превода и на библейския текст, и на тълкуванията са съвършено различни. Най-интересната от разликите

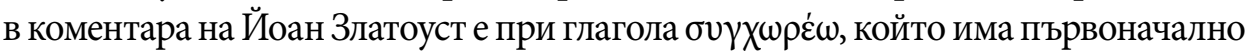
значение 'сближавам се, схождам се', а оттам - 'съгласявам се, отстъпвам' и 'прощавам'. Той е предаден с прдцати (глагол от несвършен вид, образуван от простити) в хилендарския превод и с попоустити - в рилския, т.е. и от двамата преводачи е възприет в значение 'прощавам', макар че тук по-подходящо е значението 'съгласявам се' или 'подтиквам, насърчавам'. Повече са разликите в преводите на откъса от Олимпиодор. Най-напред глаголът кү́ $\delta \omega$, който означава 'грижа се' в хилендарския превод има съответствия щд'十Тт, а в рилския - здстжпдти, което е по-точно, защото става дума за ролята на ангелите не просто да съчувстват на хората, а да ги подкрепят. По-нататък

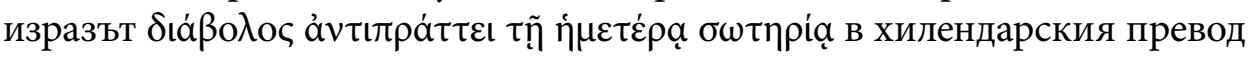




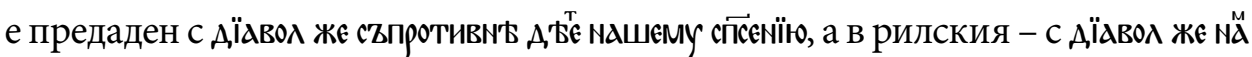
съпротивит сA, като думите за спасението са отнесени към предходната фраза, в която се говори за ангелите. Вероятно това се дължи на разлики в изходните гръцки текстове, като преводът в хилендарския превод съответства точно на текста, публикуван у Хагедорн. В края на откъса в двата превода има два синонимни глагола - съвръшдюще в хилендарския и скончАвджџє в рилския, но гръцкият текст на този израз липсва в изданието на Хагедорн. Като цяло и двата превода се придържат доста точно към гръцкия текст, като използват богатите синонимни възможности на книжовния език от XV в.

Небесният симпозиум е илюстриран в някои от гръцките ръкописи на Катената на книга Йов. На снимките може да се види и разположението на библейския текст и на коментарите в ръкописите. Очевидно илюстрациите са в съответствие с коментарите, защото дяволът не е нарисуван в общо пространство с ангелите, а е изолиран, като във Ватиканския ръкопис дори сякаш е поставен в капсула. Освен това и във Венецианския, и в Синайския ръкопис миниатюрата е повредена от опитите на по-късни читатели врагът да бъде изчегъртан, при това с настървение и явна омраза.

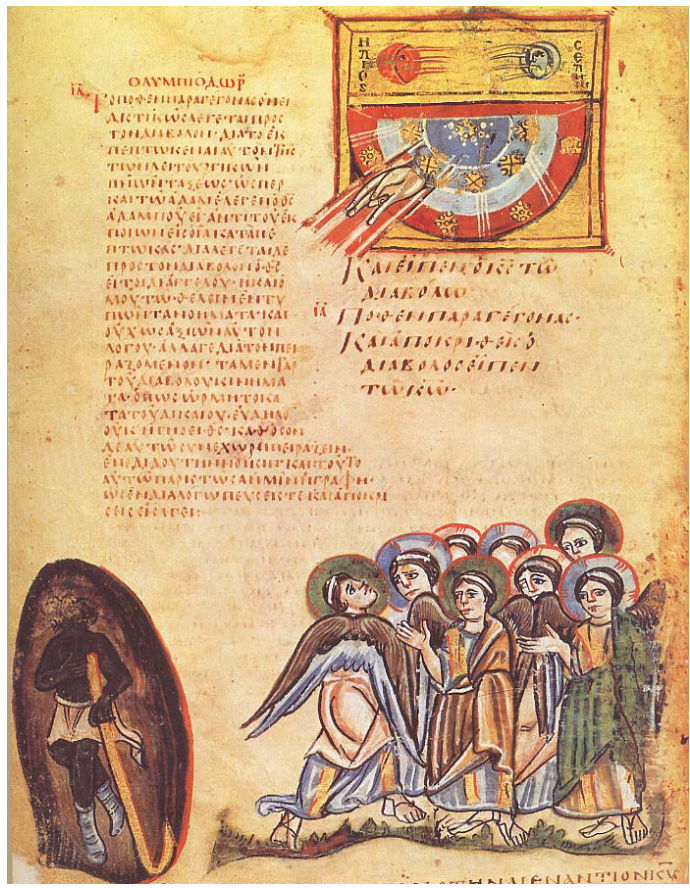

Небесният симпозиум. Йов 1:6. Миниатюра от ръкопис Vat. Gr. 749, IX в., f. 12v (по Huber, 1986, с. 99). 


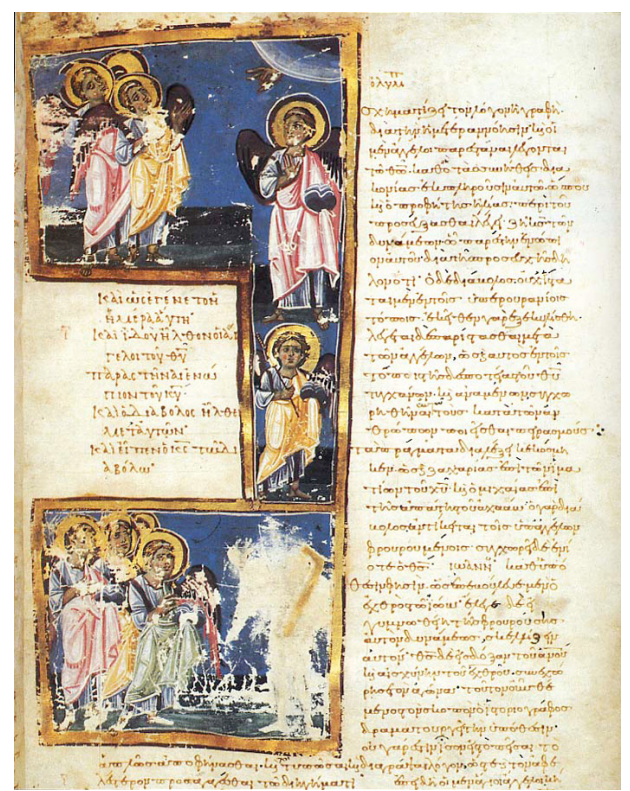

Небесният симпозиум. Йов 1:6. Миниатюра от ръкопис Venetus Marcianus. Gr. 538, 905 r. (по Huber, 1986, с. 152).

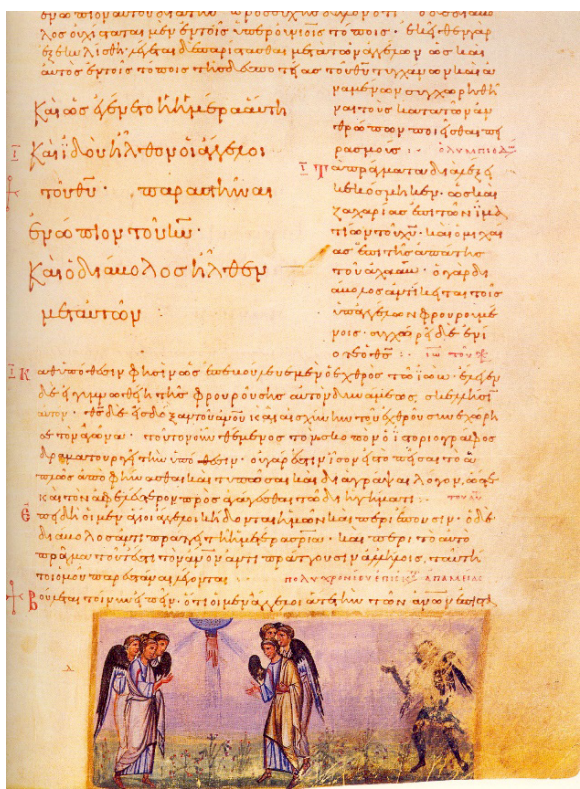

Небесният симпозиум. Йов 1:6. Миниатюра от ръкопис Sinaiticus Gr. 3, XI в., f. 13r (по Galavaris, Belezos, \& Pappa, 2002).

Миниатюристът на Йерусалимския кодекс е предпочел да не рисува сатаната, затова е изобразил ангелския събор, но не към Йов 1:6, а към 38:7, мястото, където ангелите възхваляват Съворението.

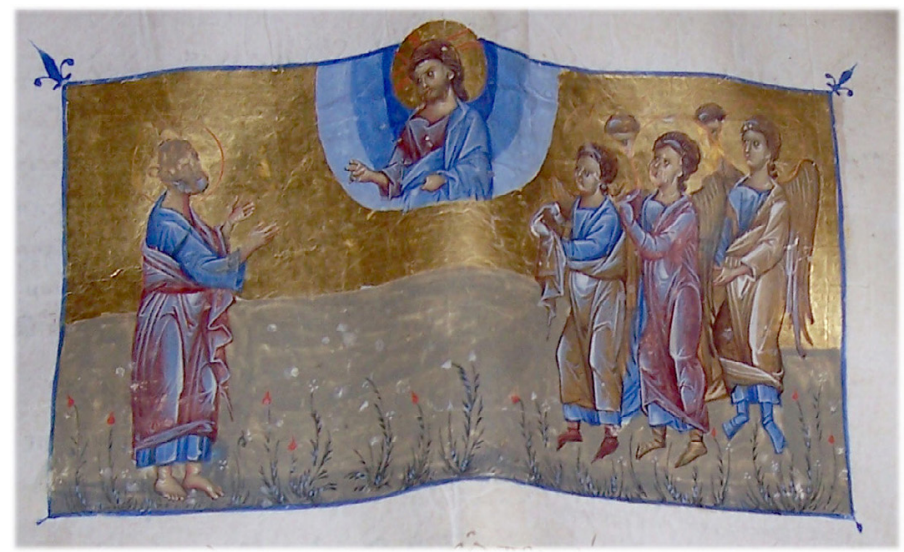

Ангелите възпяват Сътворението. Йов 38:7

Миниатюра от ръкопис Agiou Taphou 5, 1300 г., f. 231r (архив на автора) 


\section{БИБЛИОГРАФИЯ}

Ангелов, Б. (1978). Из старата българска, руска и сръбска литература. София: Издателство на Българската академия на науките.

Горский, А., \& Невоструев, К. (1857). Описание славянских рукописей Московской Синодальной библиотеки (Vol. 2/1). Москва: Синодальная (бывшая патриаршая) библиотека.

Трифуновић, Ћ. (1983). Записи инока Гавриила, преводиоца тумачења књиге о Јову. In Литературознание и фолклористика: В чест на 70-годишнината на акад. Петьр Динеков (рр. 108-111). София: Издателство на БАН.

Христова-Шомова, И. (2006). /Двата славянски превода на катената на Книга Йов. Palaeobulgarica, 30(2), 3-26.

Христова-Шомова, И. (2007). Книга Йов с тълкувания в славянски превод. По Владиславовия препис от 1456 г. София: Анубис.

Христова-Шомова, И. (2016). Бог бе слово. Етюди върху християнството, видяно през призмата на езика. София: Университетско издателство „Св. Климент Охридски“.

Яцимирский, А. И. (1905). Славянские и русские рукописи румынских библиотек. Санкт-Петербург: Тип. Имп. Акад. наук. (Сборник Отделения русского языка и словесности, 79)

Fahl, S., Harney, J., \& Fahl, D. (with Christov, I. V., Sturm, G., \& Schaper, K.). (Eds.). (2011). Das Corpus des Dionysios Areiopagites in der slawischen Übersetzung von Starec Isaija (14. Jahrhundert) (Vol. 2: Textausgabe der Handschrift Nr. 46 aus der Sammlung A. F. Hilferding der Russischen Nationalbibliothek). (H. Goltz \& G. M. Prochorov, Published under the direction). Freiburg i Br.: Weiher Verlag. (Monumenta Linguae slavicae dialecti veteris, $59(55,2))$

Galavaris, G., Belezos, K., \& Pappa, E. (2002). The Book of Job. Sinai, St. Catherine's Monastery. Codex Graecus 3. Athens: Graphida. (Facsimile edition)

Hagedorn, U., \& Hagedorn, D. (1994). Die älteren griechischen Katenen zum Buch Hiob (Vol. 1: Einleitung, Prologe und Epiloge, Fragmente zu Hiob 1,1-8,22). Berlin: De Gruyter.

Huber, P. (1986). Hiob Dulder oder Rebell?: Byzantinische Miniaturen zum Buch Hiob in Patmos, Rom, Venedig, Sinai, Jerusalem und Athos. Düsseldorf: Patmos.

Keipert, H. (1985). Die Adiektive auf-telbnz: Studien zu einem kirchenslavischen Wortbildungstyp (Part 2: Wörterverzeichnis). Wiesbaden. (Veröffentlichungen der Abteilung für Slavische Sprachen und Literaturen des Osteuropa-Instituts (Slavisches Seminar) an der Freien Universität Berlin, 45).

Reinhart, J. (2012). Христова-Шомова, И. Книга Йов с тълкувания в славянски превод. По Владиславовия препис от 1456 г. София, 2007. Slovo 62, 285-291. 


\section{BIBLIOGRAPHY}

\section{(TRANSLITERATION)}

Angelov, B. (1978). Iz starata bŭlgarska, ruska i srŭbska literatura. Sofiia: Izdatelstvo na Bŭlgarskata akademiia na naukite.

Fahl, S., Harney, J., \& Fahl, D. (with Christov, I. V., Sturm, G., \& Schaper, K.). (Eds.). (2011). Das Corpus des Dionysios Areiopagites in der slawischen Übersetzung von Starec Isaija (14. Jahrhundert) (Vol. 2: Textausgabe der Handschrift Nr. 46 aus der Sammlung A. F. Hilferding der Russischen Nationalbibliothek). (H. Goltz \& G. M. Prochorov, Published under the direction). Freiburg i Br.: Weiher Verlag. (Monumenta Linguae slavicae dialecti veteris, $59(55,2))$

Galavaris, G., Belezos, K., \& Pappa, E. (2002). The Book of Job. Sinai, St. Catherine's Monastery. Codex Graecus 3. Athens: Graphida. (Facsimile edition)

Gorskiĭ, A., \& Nevostruev, K. (1857). Opisanie slavianskikh rukopiseı̆ Moskovskoŭ Sinodal'noı̆ biblioteki (Vol. 2/1). Moskva: Sinodal'naia (byvshaia patriarshaia) biblioteka.

Hagedorn, U., \& Hagedorn, D. (1994). Die älteren griechischen Katenen zum Buch Hiob (Vol. 1: Einleitung, Prologe und Epiloge, Fragmente zu Hiob 1,1-8,22). Berlin: De Gruyter.

Huber, P. (1986). Hiob Dulder oder Rebell?: Byzantinische Miniaturen zum Buch Hiob in Patmos, Rom, Venedig, Sinai, Jerusalem und Athos. Düsseldorf: Patmos.

IAtsimirskiŭ, A. I. (1905). Slavianskie i russkie rukopisi rumynskikh bibliotek. Sankt-Peterburg: Tip. Imp. Akad. nauk. (Sbornik Otdeleniia russkogo iazyka i slovesnosti, 79)

Keipert, H. (1985). Die Adiektive auf-telbnz: Studien zu einem kirchenslavischen Wortbildungstyp (Part 2: Wörterverzeichnis). Wiesbaden. (Veröffentlichungen der Abteilung für Slavische Sprachen und Literaturen des Osteuropa-Instituts (Slavisches Seminar) an der Freien Universität Berlin, 45).

Khristova-Shomova, I. (2006). Dvata slavianski prevoda na katenata na Kniga Ǐov. Palaeobulgarica, 30(2), 3-26.

Khristova-Shomova, I. (2007). Kniga Ĭov s tŭlkuvaniia v slavianski prevod. Po Vladislavoviia prepis ot $1456 \mathrm{~g}$. Sofiia: Anubis.

Khristova-Shomova, I. (2016). Bog be slovo. Etiudi vŭrkhu khristiianstvoto, vidiano prez prizmata na ezika. Sofiia: Universitetsko izdatelstvo "Sv. Kliment Okhridski“.

Reinhart, J. (2012). Khristova-Shomova, I. Kniga Ĭov s tŭlkuvaniia v slavianski prevod. Po Vladislavoviia prepis ot $1456 \mathrm{~g}$. Sofiia, 2007. Slovo 62, 285-291.

Trifunović, Ć. (1983). Zapisi inoka Gavriila, prevodioca tumačenja knjige o Jovu. In Literaturoznanie i folkloristika: V chest na 70-godishninata na akad. Petŭr Dinekov (pp. 108-111). Sofiia: Izdatelstvo na BAN. 


\section{Niebiańskie sympozjum. Komentarze do Księgi Hioba $(1,6)$ w bizantyńskiej i słowiańskiej tradycji}

Werset 1,6 Księgi Hioba jest jednym z wielu miejsc w Biblii, w którym wspomina się synów Bożych: „Zdarzyło się pewnego dnia, gdy synowie Boży udawali się, by stanąć przed Panem, że i szatan też poszedł z nimi”. Ogromna liczba komentarzy Ojców Kościoła do Księgi Hioba została zawarta w greckiej katenie. Niektóre z nich nie zostały napisane jako bezpośredni komentarz do tego wersetu, lecz są wypisami z prac autorów, komentującymi naturę aniołów, ich miejsce w Bożej opatrzności, a także rolę w życiu ludzkim. Ponadto istniały dwa słowiańskie przekłady kateny. Pierwszy zawierał większość tekstów pochodzących z greckiej kateny, a drugi składał się zaledwie z dwóch passusów, będących wyimkami z komentarzy św. Jana Chryzostoma i Olimpiododrosa.

W artykule porównano teksty słowiańskie, które zostały przetłumaczone z języka greckiego na Bałkanach w tym samym czasie: pod koniec wieku XIV lub na początku XV. W artykule przedstawiono również kilka miniatur pochodzących ze średniowiecznych greckich rękopisów, przedstawiających niebiańskie sympozjum.

Słowa kluczowe: niebiańskie sympozjum, katena, komentarz biblijny, przekład słowiański

\section{Celestial Symposium: Commentaries to the Book of Job 1:6 in the Byzantine and Slavic Traditions}

Job 1:6 is one of several places in the Bible where God's sons (celestial beings) are mentioned: "One day the sons of God came to present themselves before the Lord, and Satan also came among them." Numerous commentaries of the Church Fathers were included in the Greek catena to the Book of Job. Some of these were not written specially as commentaries to this passage but are extracts from works commenting the nature of the angels, their place in God's providence and their role in human life. The author then goes on to discuss the two Slavic translations that were made of the catena. The first one comprises the majority of the texts included in the Greek catena, while the second one contains only two small passages from commentaries of Saint John Chrysostom and Olympiodoros. The article provides a comparison between Slavic texts, which were translated from Greek in the Balkans at the same time: in the late fourteenth or early fifteenth century. Several miniatures from medieval Greek manuscripts, which illustrate the Celestial symposium, are represented at the end of the article.

Keywords: Celestial Symposium, catena, biblical commentary, Slavic translation 


\section{Notka o autorze}

Iskra Hristova-Shomova (Искра Христова-Шомова) (iskrashomova@gmail. com) - językoznawczyni, profesor Uniwersytetu im. św. Klemensa z Ochrydy w Sofii, wykładowczyni języka starobułgarskiego (staro-cerkiewno-słowiańskiego) i lingwistyki tekstu na Wydziale Filologii Słowiańskich. Autorka książek: Речник на словата на Климент Охридски (1994), Служебният Апостол в славянската ръкописна традиция (t. 1-2, 2004-2012), Книга Йов с тблкувания в славянски превод (2007). Zainteresowania naukowe: historia i dialekty języków słowiańskich, starosłowiańskie przekłady Biblii i ich rewizje, liturgia słowiańska i bizantyńska, antropologia kultury i języka, manuskrypty starosłowiańskie.

Iskra Hristova-Shomova, Professor (iskrashomova@gmail.com) - linguist, lecturer in Old Bulgarian (Old Church Slavonic) and text linguistics at the Faculty of Slavonic Studies, Sofia University. Author of the books: Rechnik na slovata na Kliment Ohridski (1994); Sluzhebniyat Apostol v slavyanskata rakopisna tradiciya (Vol. 1-2, 2004-2012); Kniga Yov s talkuvaniya v slavyanski prevod (2007). Research interests: history and dialects of Slavic languages; Old Slavonic translations of the Bible and their revisions; Slavic and Byzantine liturgy; language and cultural anthropology; Old Slavic manuscripts. 